\title{
Influence of Directive and Achievement Oriented Path-Goal Leadership Styles on Employee Performance of Coffee Trading Companies in Kenya
}

\author{
Rozmina Rana* George K'Aol Michael Kirubi \\ Chandaria School of Business, United States International University - Africa, Nairobi, Kenya, P.O Box 14634, \\ Toronto 00800, Kenya
}

\begin{abstract}
The study sought to examine the extent to which directive and achievement-oriented path-goal leadership styles influence employee performance of coffee trading companies in Kenya. The positivism philosophy was adopted and the design used was a descriptive correlational research design. The population for the study was 180 senior managers of coffee trading companies in Kenya. Using stratified random sampling technique, a sample size of 139 was determined from the total population and structured questionnaires were administered to collect primary data. Out of 139 questionnaires administered, 117 questionnaires were successfully completed, representing a response rate of $84.2 \%$. Descriptive and inferential statistics were used to analyze the data. The descriptive statistics were mean and standard deviation while the inferential statistical analysis included correlational analysis, chi-square and multiple linear regression analysis. The results of the multiple linear regression analysis revealed that directive leadership style negatively and significantly predicted employee performance, $R^{2}=0.035$, $F(1,114)=4.141, \quad p \leq .05, \beta=-0.153, p \leq .05$. Multiple linear regression analysis further revealed that achievement oriented leadership style positively and significantly predicted employee performance, $\mathrm{R}^{2}=0.161$, $\mathrm{F}(1,116)=20.686, \mathrm{p} \leq .05, \beta=0.391, \mathrm{p} \leq .05$. The study provided a unique contribution to theory and practice of leadership by contributing to knowledge in the application of Path-goal leadership styles in coffee trading companies. The study findings led to the conclusion that the use of directive leadership style in coffee trading companies can adversely affect performance and leaders should avoid its use. On the other hand, achievement oriented leadership style positively and significantly affects employee performance of coffee trading companies. Leaders of coffee trading companies should engage in goal setting, give feedback to employees on the progress on their goals and reward employees for achieving their goals. These behaviors will motivate employees and enhance their performance. Recommendations for further research are that scholars should carry out similar studies for supervisory level managers to assess the influence of path goal leadership styles on employees at this level.
\end{abstract}

Keywords: key words, orkforce sizing, job-shop production, holonic model

DOI: $10.7176 / \mathrm{JEP} / 10-19-04$

Publication date:July $31^{\text {st }} 2019$

\section{INTRODUCTION}

\subsection{Background of the Study}

It is vital that organizations strive to continually improve the performance of their employees (Sougui, Bon \& Hassan, 2015). Iqbal, Anwar, and Haider (2015) refer to leadership as a practice where an executive directs, guides and influences the actions and work of others to enable them to attain desired outcomes in the given circumstances. A leader exerts influence to improve the performance of followers by using strategies or tactics and by applying behaviors designed to change attitudes, beliefs, values or actions (Nikoloski, 2015). The pathgoal-theory focuses on the behavior of leaders in motivating job satisfaction and job performance of the followers.

The path goal theory has its base on the expectancy theory (Vroom, 1964). This expectancy theory poses that a person behaves in a certain way because of an expectation that the behavior will result in a particular outcome. The path-goal theory argues that managers motivate their employees to perform by using different behaviors appropriate to the work settings and subordinate needs, and the leader's behavior will affect the amount of effort exerted by the employee and therefore impact upon his or her overall performance. There are four leadership styles under the path-goal theory that a leader can apply and these are directive, participative, supportive and achievement oriented.

To extract potential and optimize the value employees bring to an organization, the leadership styles or behaviors employed are important determinants as they affect the obligation of the employees to the company (Javaid, 2012). To achieve optimal employee commitment, organizational success and effectiveness, the leadership behavior should include motivation, encouragement and joint decision making (Abbah, 2014). Nikoloski (2015) also found that attractiveness of the outcomes served to motivate the individual and increase performance at work. A leader must be capable of identifying the activities employees need to engage in so as to 
achieve the goals of the organization. The path-goal theory argues that managers motivate their employees to perform well and the manager's behavior will affect the amount of effort exerted by the employee as well as his or her overall performance. This study focused on the influence of directive and achievement-oriented leadership style on employee performance.

\subsection{Statement of the Problem}

The coffee sector is a key contributor to Kenya's gross domestic product and provides employment to millions of nationals. While it was Kenya top foreign exchange earner, in the decades following independence, the performance of the sector has been declining. The government has been banking on revival and growth of coffee earnings to realize Kenya's vision to industrialize and transform into a middle income nation by the year 2030 (Kenya Vision 2030, 2007). Path-goal theory of leadership asserts that leaders can adapt their styles to enhance employee performance (Henseler, Ringle \& Sinkovics, 2015). Though there is a growing body of literature on the influence of leadership styles on employee performance, the studies are far from adequate (Wakabi, 2016). Lumbasi et al. (2016) recommended that future studies should consider the influence of path-goal leadership styles on employee performance of specific industries. Considering the vital role of the coffee industry to the economy of Kenya, it is of immense value to examine the influence of path-goal leadership styles on the performance of employees of coffee trading companies.

If the performance of the coffee sector is not improved and the adverse trends are not halted, there could be adverse consequences to the sustainability of millions of Kenyans who depend on coffee for their livelihood (Kieyah \& Lesiyampe, 2016). Investing efforts to boost the performance of the coffee industry can return the sector to its historical prominent position of being one of the highest foreign exchange earners for Kenya (Monroy, Mulinge \& Witwer, 2013). It is evident that leaders can motivate employees to achieve enhanced performance. In the US, experts credited the leadership style of the chief executive officer of The Starbucks Coffee Company, Howard Schultz to reviving the company from poor performance in the year 2008 and transforming it to a global leader in coffee brands (Flamholtz \& Randell, 2016). Globally, researchers (Martin, 2014; Mahdi et al., 2014; Malik 2013; Iqbal et al. 2015) have demonstrated the influence of leadership styles on employee performance. In Kenya, a study by Namusonge and Koech (2012) found that path-goal leadership styles significantly affected the performance of workers in state corporations and a study by Wanjala (2014) had similar findings for the hospitality industry. There was a scarcity of literature in the field of coffee trading companies and this study sought to fill this knowledge gap by examining the influence of two path-goal leadership styles on employee performance.

\subsection{Research Purpose}

The purpose of the study was to examine the influence of directive and achievement-oriented leadership styles on employee performance of coffee trading companies in Kenya.

\subsection{Research Questions}

1.4.1 To what extent does directive leadership style influence employee performance of coffee trading companies in Kenya?

1.4.2 To what extent does achievement-oriented leadership style influence employee performance of coffee trading companies in Kenya?

\subsection{Research Hypothesis}

1.5.1 $\mathrm{H}_{01}$ : Directive leadership style does not have a significant influence on employee performance of coffee trading companies in Kenya.

1.5.2 $\quad \mathrm{H}_{02}$ : Achievement leadership style does not have a significant influence on employee performance of coffee trading companies in Kenya.

\subsection{LITERATURE REVIEW}

\subsection{Theoretical Review}

The study was underpinned by the Path-goal leadership theory which has its base on Vrooms expectancy theory. This theory considers leaders as lenient or flexible individuals who can adjust their style of leading based on the situation at hand (Northouse, 2013). The theory suggests that there are two contingency variables namely the environment and the follower characteristics (Lussier \& Achua, 2013). The theory has several constructs which are the four leadership behaviors or styles, environmental contingency factors, subordinate contingency factors and finally the outcomes.

Path-goal theory was developed by developed by House in 1971 and refined by House again in the year 1996 (Evans, 1970; House \& Mitchell, 1974; House, 1996). The path-goal theory has been described as one of the most respected approaches to leadership and the term 'path-goal' is derived from the belief that effective 
leaders need to clarify the path for their followers to achieve their work goals (Robbins \& Judge, 2013). The path-goal theory assumes flexibility on the part of leaders and suggests that leaders should choose behaviors that best suit subordinate needs and work situations. Essentially, a leader can help subordinates by selecting a style of leadership that provides what is missing in a particular work setting (Northouse, 2013).

\subsection{Conceptual Framework}

Figure 1 presents conceptual framework for the study. Conceptual frameworks are mental maps show the relationships between interplay of variables graphically and diagrammatically (Marshll \& Rossman, 2016). This conceptual framework illustrated below comprises of the independent variables which are directive and achievement oriented leadership styles and the dependent variable is employee performance.

\section{Independent Variables}

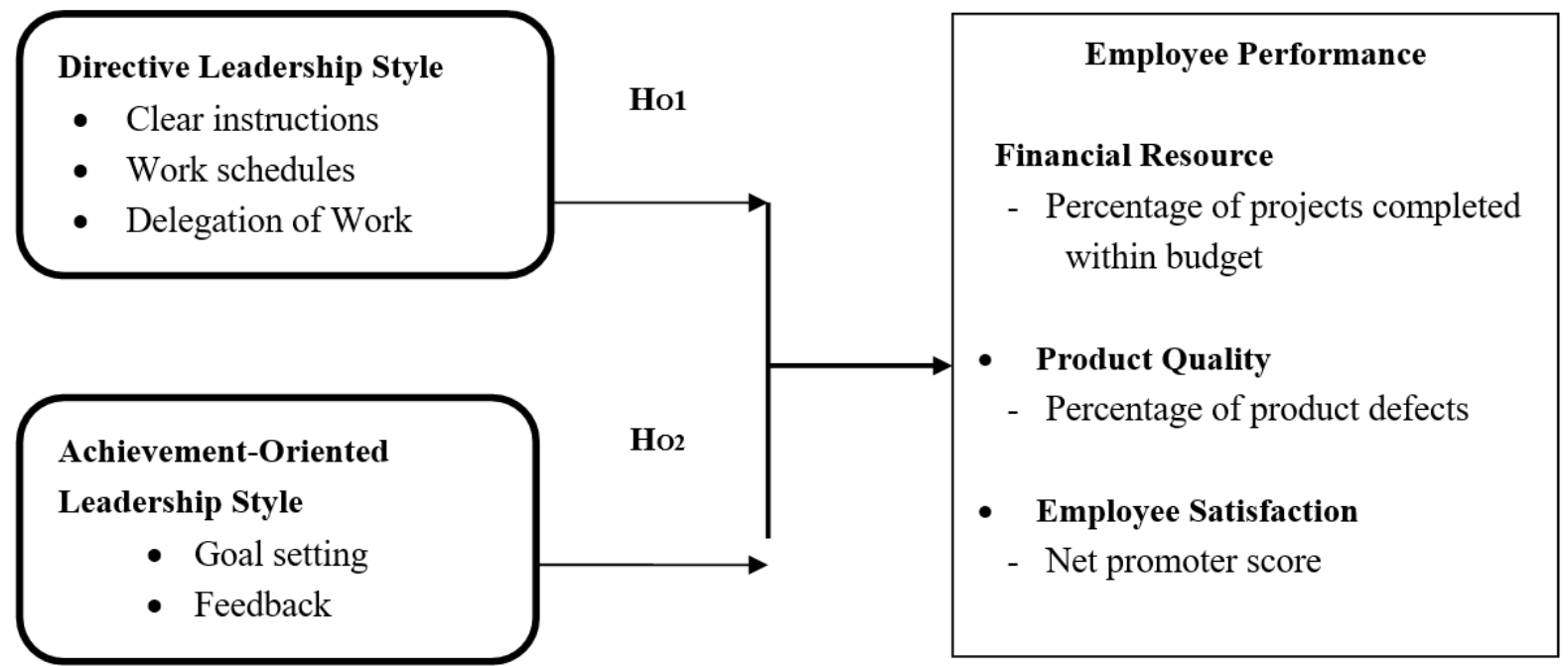

Figure 1. Conceptual Framework.

\section{Dependent Variable}

\section{Employee Performance}

Financial Resource

Percentage of projects completed within budget

Product Quality

Percentage of product defects

- Employee Satisfaction

Net promoter score

\subsubsection{Empirical Review}

The studies that have been carried out recently on directive and achievement-oriented leadership styles and employee performance are discussed in this section.

\subsubsection{Directive Leadership and Employee Performance}

This section presents an empirical review of studies that demonstrate the effect of leaders deploying directive leadership style on employee performance. The literature has been analyzed and is presented for the constructs for directive leadership style for this study which were clear instructions, work schedules and delegation of work. Ojokuku, Odetayo and Sajuyigbe (2014) describe directive leadership style as situations where leaders give complete and essential directives. In directive leadership behavior, questions like what needs to be done, where it needs to be done, how it should be done and who should do the different parts of the job in question are very clearly specified. A leader makes clear the expectations he or she has of those under his command and exercises full control over any plans and work scheduling, and employees have to adhere to all the established procedures and meet the expected standards. Simply put, leaders using this style explain followers' roles and give a clear picture of what they expect.

A study by Wachira, Tanui and Kalai (2016) found a positive and significant relationship between directive leadership style of head teachers and job satisfaction of teachers in public primary schools in Nakuru (rho (305) $=0.592, \mathrm{p} \leq 0.05)$. Chege, Wachira and Mwenda (2015) conducted a study which examined the effect of leadership styles on the implementation of strategic plans on 354 small and medium sized organizations. The results revealed that directive leadership style positively and significantly affected the implementation of strategic plans.

On the other hand, other studies have shown negative associations between directive leadership style and employee performance. Basit, Sebastian and Hassan (2017) undertook a study on the effect of leadership styles on employee performance in a private organization in Malaysia. The constructs used in their study to determine the existence of directive leadership style included leader assessments, defined policies, orders and procedures, rewards and punishments to get better performance and refusal by a leader to explain his or her actions. The findings of their study revealed that directive leadership style had a negative and significant effect on employee performance. Another study by Mendez, Munoz and Munoz (2013) of small construction companies in Mexico 
found that there was a negative correlation between the behavior of leaders who initiated structure clearly specifying how the work needed to be done and the percentage of projects completed within budget $(r=-0.145$, $\mathrm{p} \leq 0.05$ ). Finally, a study conducted by Euwema, Wendt and van Emmerik (2014) investigated the relationship between directive leadership and group organizational citizenship behavior (GOCB). This study used data from the database of an international consulting organization (Hays Group) who had gathered data from managers and team members in 33 countries. The hypotheses tested with multi-level analysis indicated that directive leadership was negatively related with GOCB. The study further found that the adoption of rules, procedures, and routine practices as advocated for by leaders using directive leadership style had a negative impact on the quality of products the teams produced and attributed this largely to trust being compromised as a result of the leader's rigid behavior.

Directive leadership style also has the effect of instilling fear in followers and Posner (2012) posed that a leader-constituent relationship characterized by fear and distrust never produces anything that is of great quality or of lasting value. This said, directive leadership behavior has been found helpful and suitable in instances where the task that are assigned to employees to complete are complex or ambiguous. The formal authority offered by directive leadership style is strong and helps subordinates get clarity on how the tasks have to be performed (Lussier\& Achua, 2013). Setting of performance standards and giving clear rules and regulations with explicit expectations of performance for subordinates can be helpful under circumstances where individuals lack the competencies to perform tasks (Malik, Aziz \& Hassan, 2014; Northouse, 2016).

\subsubsection{Achievement-Oriented Leadership style and Employee Job Performance}

This section presents an empirical review of studies that demonstrate the effect of leaders deploying achievement oriented leadership style on employee performance. The literature has been analyzed and is presented for the constructs for achievement oriented leadership style for this study which were goal setting, feedback and rewards. Leadership has always been a crucial issue with organizations and companies permanently striving to enhance their competitiveness. While there is no universal definition of the concept of leadership, the bulk of definitions in the literature reviewed emphasize that fundamentally, leadership is aimed at maximizing efficiency and achieving organizational goals (Northouse, 2016; Yukl, 2014; Timmerman, 2012). The underlying assumption that goal setting leads to greater productivity has gained popularity over the years and has resulted in individuals being encouraged to set personal and professional goals in order to be productive and not risk losing out on what they desire. Under the path-goal theory, achievement oriented leaders motivate subordinates to achieve challenging goals.

A study by Lumbasi, K'aol and Ouma (2016) on 84 senior managers of 13 companies who had won the Company of the Year Award in Kenya found that the application of achievement oriented leadership style had significant positive influence on employee performance. Recommendations were that leaders should create working reward systems defining benefits for employees who effectively attained set goals and create a supportive environment for set goals to be accomplished in the set time period. A study by Polston-Murdoch (2013) examined the impact of leadership styles on employee satisfaction. The findings revealed that leaders who use two leadership styles, namely participative and achievement-oriented leadership styles, attain better employee performance outputs than other path-goal leadership styles.

According to Sherren (2014), the best managers focus more on getting staff to work together and make people feel their personal efforts are valued; they create a culture where people are inspired to set goals, take calculated risks and have control over their work for greater quality. Information given to employees on their performance can affect the future performance of an employee. Feedback, and the form in which it is given, can affect employee motivation and therefore his or her satisfaction and performance. As an expectancy theory, it also follows that the expectation of an employee of feedback can also affect how much more effort the employee may voluntarily put into the tasks at hand. According to Malik (2013), when an employee is convinced that there is no difference between the treatment of a high performer and a poor performer, individuals stop putting extra effort or aiming for higher quality productivity hence undermining employee performance. Extra effort in achieving higher product quality has been associated with high employee performance (Elorza, Harris, Aritzeta, \& Balluerka, 2016).

On the other hand, it is not always the case that achievement oriented leadership results in greater productivity. The findings of a study by Sagnak (2016) found that goal-focused leadership led to high levels of emotional exhaustion for subordinates who were low in conscientiousness and emotional stability. Despite the fact that over-achieving leaders may be successful in driving subordinates to greater productivity, they need to be mindful of the 'dark side' to the achievement motive by leaders. Leaders who relentlessly focus on tasks and goals such as driving for unrealistically high revenues or sales targets could damage performance over time. Overachievers tend to command and coerce, rather than coach and collaborate, thus stifling subordinates; they frequently take shortcuts, forget to communicate crucial information, may be oblivious to the concerns of others and their teams' performance therefore begins to suffer and they risk missing the very goals that initially triggered the achievement-oriented behaviors on their part (Spreier, Fontaine \& Malloy, 2016). 


\subsection{RESEARCH METHODOLOGY}

This study adopted the positivism philosophy. The target population of the study consisted of 180 senior managers. A sample size of 139 senior managers was drawn using stratified random sampling. Data was collected using self-administered questionnaires. The data was then analyzed using descriptive statistics of frequency and percentage distribution, mean and standard deviation. Additionally, inferential data analysis methods were used. These include: Pearson's correlation, Chi-square, ANOVA, and simple linear regression that were used to test the hypotheses.

\subsection{RESULTS AND FINDINGS}

The results and findings of the analysis of the data are presented in this section based on the demographic information and research questions.

\subsection{Demographic Information}

The study sought information on the respondents age groups, their gender, and the number of years of work experience. Out of the total respondents, $26.5 \%$ were finance managers, $21.4 \%$ were quality control managers, $23.1 \%$ were trading managers and $29.0 \%$ were human resource managers.

In terms of the age-groups of the respondents, $17.09 \%$ of the respondents were over 55 years, $58.12 \%$ were in the 41 to 55 years age bracket, $23.08 \%$ were in the 26 to 40 years age bracket and $0.85 \%$ were in the 18 to 25 years age bracket.

The gender of $48.7 \%$ of the respondents was female while that of $51.3 \%$ was male.

In terms of the number of years of work experience $49.6 \%$ of the respondents had worked for their organizations for over ten years, $29.1 \%$ had worked for their organizations for between seven to ten years, $20.5 \%$ had worked for their organizations for between 4 to 6 years and $0.9 \%$ had worked for their organizations for three years or less.

\subsection{Directive Leadership}

\subsubsection{Descriptive Statistics}

The objective of the study was to examine the extent to which directive leadership style influenced performance of senior managers of coffee trading companies in Kenya. Table 1 shows the means and standard deviations for the responses to the questions which examined the influence of directive leadership style on employee performance of coffee trading companies.

Table 1: Mean (M) and Standard Deviation (S.D) for Directive Leadership Style

\begin{tabular}{|c|c|c|c|}
\hline Directive Leadership Style & $\mathbf{N}$ & (M) & (SD) \\
\hline My supervisor provides clear instructions that employees must follow & 116 & 4.30 & .479 \\
\hline My supervisor provides employees with work schedules & 116 & 4.22 & .545 \\
\hline My supervisor delegates work to the respective employees & 116 & 4.24 & .487 \\
\hline \multicolumn{4}{|l|}{ Influence of Directive Leadership Style on the Effective use of Financial Resources } \\
\hline $\begin{array}{l}\text { To what extent does provision of clear instructions by your supervisor affect the effective } \\
\text { use of financial resources by employees? }\end{array}$ & 116 & 3.62 & .809 \\
\hline $\begin{array}{l}\text { To what extent does provision of work schedules by your supervisor affect the effective use } \\
\text { of financial resources by employees? }\end{array}$ & 116 & 3.67 & .852 \\
\hline $\begin{array}{l}\text { To what extent does delegation of work by your supervisor to respective employees affect } \\
\text { the effective use of financial resources by employees? }\end{array}$ & 116 & 3.53 & .763 \\
\hline \multicolumn{4}{|l|}{ Influence of Directive Leadership Style on Product Quality } \\
\hline $\begin{array}{l}\text { To what extent does provision of clear instructions by your supervisor affect the quality of } \\
\text { products produced by employees? }\end{array}$ & 116 & 4.36 & .581 \\
\hline $\begin{array}{l}\text { To what extent does provision of work schedules by your supervisor affect the quality of } \\
\text { products produced by employees? }\end{array}$ & 116 & 4.36 & .610 \\
\hline $\begin{array}{l}\text { To what extent does delegation of work by your supervisor to respective employees affect } \\
\text { the quality of products produced by employees? }\end{array}$ & 116 & 4.38 & .599 \\
\hline \multicolumn{4}{|l|}{ Influence of Directive Leadership Style on Employee Satisfaction } \\
\hline $\begin{array}{l}\text { Considering your supervisor's provision of clear instructions to employees, how likely are } \\
\text { you to refer friends and family to work in your organization? }\end{array}$ & 116 & 4.16 & .416 \\
\hline $\begin{array}{l}\text { Considering the provision of work schedules to employees by your supervisor, how likely } \\
\text { are you to refer friends and family to work in your organization? }\end{array}$ & 116 & 4.70 & 607 \\
\hline $\begin{array}{l}\text { Considering the delegation of work to employees by your supervisor, how likely are you to } \\
\text { refer friends and family to work in your organization? }\end{array}$ & 116 & 3.59 & .770 \\
\hline
\end{tabular}


Directive Leadership Style Influence of Directive Leadership Style on Innovation

\begin{tabular}{|l|l|l|l|}
\hline To what extent does provision of clear instructions to employees by your supervisor affect & 114 & 3.08 & .551
\end{tabular} the generation of new ideas in your organization?

To what extent does provision of work schedules to employees by your supervisor affect the generation of new ideas by employees?

To what extent does delegation of work to respective employees by your supervisor affect

the generation of new ideas by employees in your organization?

The results in Table 1 indicates that, on average, the respondents agreed that provision of clear instructions by their supervisors affected the effective use of financial resources by employees $(M=3.62, S . D=0.809)$, they also agreed that the provision of work schedules by supervisors affected the quality of products produced $(M=$ 4.36, $S . D=0.610)$. Respondents were neutral on whether or not provision of work schedules by their supervisors affected the generation of new ideas $(M=2.99, S . D=0.587)$, but they agreed that delegation of work to employees by their supervisors increased the likelihood of their referring friends and families to work for the organization $(M=3.59$, S.D $=0.770)$. Finally, the results indicated that the resondents were neutral about whether or not delegation of work to respective employees affected the generation of new ideas $(M=3.09, S . D=$ $0.558)$.

\subsubsection{Correlations between Directive Leadership Style and Employee Performance}

Correlation analysis was conducted to examine the strength and direction of the relationship between directive leadership style and employee performance of senior managers of coffee trading companies in Kenya.

The results in Table 2 revealed that there was a negative and significant correlation between directive leadership style and employee performance, $r(116)=-.187, p \leq .05$.

Table 2: Correlation between for Directive Leadership Style and Employee Performance

\begin{tabular}{|l|l|l|l|}
\hline \multicolumn{2}{|c|}{} & Directive Leadership Style & Employee Performance \\
\hline \multirow{4}{*}{ Directive Leadership Style } & Pearson Correlation & 1 & $-.187^{*}$ \\
\cline { 2 - 4 } & Sig. (2-tailed) & & .044 \\
\cline { 2 - 4 } & $\mathrm{N}$ & 116 & 116 \\
\hline \multirow{3}{*}{ Employee Performance } & Pearson Correlation & $-.187^{*}$ & 1 \\
\cline { 2 - 4 } & Sig. (2-tailed) & .044 & 116 \\
\cline { 2 - 4 } & $\mathrm{N}$ & 116 & 116 \\
\hline
\end{tabular}

4.2.3 Chi-Square Test for Directive Leadership Style and Employee Performance

The study sought to examine whether there was a statistically significant association between directive leadership style and employee performance. Table 3 shows the results of the chi-square test for directive leadership style and employee performance.

Table 3: Chi-square Test for Directive Leadership Style

\begin{tabular}{|l|l|}
\hline & Directive Leadership Style \\
\hline Chi-Square & $311.439^{\mathrm{a}}$ \\
\hline df & 90 \\
\hline Asymp. Sig. (2-sided) & .000 \\
\hline
\end{tabular}

The results indicate that there was sufficient evidence to conclude that there is a statistically significant association between directive leadership style and employee performance $\chi^{2}(90, N=117)=311.439, p \leq .05$.

\subsubsection{Regression Analysis and Hypothesis Testing}

Multiple linear regression analysis is conducted to explore whether one or more predictor variables explain the dependent variable. The following hypothesis was tested:

$\mathbf{H}_{01}$ : Directive leadership style does not have a significant effect on employee performance of coffee trading companies in Kenya.

\subsubsection{Regression Model Summary}

The study findings revealed that directive leadership style explained 3.5\% variation in employee performance among the senior managers of coffee trading companies, $R^{2}=.035$. This implies that $3.5 \%$ of the changes in employee performance among senior managers could be explained by the directive leadership style. The findings of the regression model for employee performance and directive leadership style is shown in Table 6 .

Table 4: Regression Model Summary for Directive Leadership Style Model Summary

\begin{tabular}{|l|l|l|l|l|}
\hline Model & R & R Square & Adjusted R Square & Std. Error of the Estimate \\
\hline 1 & $.187^{\mathrm{a}}$ & .035 & .027 & .35276 \\
\hline
\end{tabular}

a Predictors: (Constant), Directive Leadership Style

b Dependent Variable: Employee Performance 


\subsubsection{Regression ANOVA}

The regression ANOVA results are represented in Table 5.

Table 5: Regression ANOVA for Directive Leadership Style and Employee Performance

\begin{tabular}{|l|l|l|l|l|l|l|}
\hline \multicolumn{2}{|l|}{ Model } & Sum of Squares & df & Mean Square & F & Sig. \\
\hline \multirow{3}{*}{1} & Regression & .515 & 1 & .515 & 4.141 & $.044^{\mathrm{b}}$ \\
\cline { 2 - 7 } & Residual & 14.186 & 114 & .124 & & \\
\cline { 2 - 6 } & Total & 14.701 & 115 & & & \\
\hline & $\begin{array}{l}\text { a. Dependent Variable: Employee Performance } \\
\text { b. Predictors: (Constant), Directive Leadership Style }\end{array}$ \\
Correlation is significant at the 0.05 level (2 tailed).
\end{tabular}

The results in Table 5 indicate that the model was statistically significant in linking directive leadership style and employee performance of senior managers of coffee trading companies in Kenya, $F(1,114)=4.141, p$ $\leq .05$.

\subsubsection{Regression Coefficients}

The results of the regression coefficient for directive leadership style and employee performance are presented in Table 6.

Table 6: Regression Coefficients for Directive Leadership Style and Employee Performance

\begin{tabular}{|c|c|c|c|c|c|c|}
\hline & & $\begin{array}{l}\text { Unstar } \\
\text { Coeffi }\end{array}$ & $\begin{array}{l}\text { ized } \\
\text { s } \\
\end{array}$ & $\begin{array}{l}\text { Standardized } \\
\text { Coefficients }\end{array}$ & & \\
\hline & & $\mathrm{B}$ & Std. Error & Beta & $\mathrm{t}$ & Sig. \\
\hline 1 & (Constant) & 4.449 & .321 & & 13.853 & .000 \\
\hline & Directive Leadership Style & -.153 & .075 & -.187 & -2.035 & .044 \\
\hline
\end{tabular}

a. Dependent Variable: Employee Performance

These study findings in Table 6 indicate that directive leadership style negatively and significantly predicts employee performance, $\beta=-.153, t(115)=-2.035, p \leq .05$. This implied that a unit increase in directive leadership style would lead to a decrease in employee performance among the senior managers of coffee trading companies in Kenya by 0.153 units. The study therefore concluded that directive leadership style negatively and significantly predicted employee performance of senior managers of coffee trading companies in Kenya.

\subsection{Achievement-Oriented Leadership Style}

\subsubsection{Descriptive Statistics}

The objective of the study was to examine the extent to which achievement-oriented leadership style affected performance of senior managers of coffee trading companies in Kenya.

Table 7 shows the means and standard deviations for the responses to the questions which examined the influence of achievement-oriented leadership style on employee performance of coffee trading companies.

The results revealed that on average, the respondents agreed that defining clear goals affected the effective use of financial resources by employees in the organization $(M=4.05, S D=0.475)$. It was found that the respondents were neutral on the statement that requiring feedback on the achievement of goals by employees affected the quality of products produced by employees in the organization $(M=3.26, S D=0.643)$.

Table 7: Mean and Standard Deviation for Achievement-Oriented Leadership Style Descriptive Statistics

\begin{tabular}{|c|c|c|c|}
\hline Achievement-Oriented Leadership Style & $\mathbf{N}$ & (M) & (SD) \\
\hline In my company, my supervisor defines clear goals for employees to achieve & 117 & 4.23 & .515 \\
\hline $\begin{array}{l}\text { In my company, employees are required to give feedback on the achievement of goals set } \\
\text { by the supervisor. }\end{array}$ & 117 & 4.18 & .448 \\
\hline $\begin{array}{l}\text { In my company, employees are rewarded by the supervisor after successfully } \\
\text { accomplishing tasks. }\end{array}$ & 117 & 4.08 & .559 \\
\hline \multicolumn{4}{|l|}{ Effects of Achievement-Oriented Leadership Style on the Effective use of Financial Resources } \\
\hline $\begin{array}{l}\text { To what extent does the role by your supervisor in defining clear goals affect the effective } \\
\text { use of financial resources by employees in your organization? }\end{array}$ & 115 & 4.05 & .475 \\
\hline $\begin{array}{l}\text { To what extent does the behavior by your supervisor in requiring feedback on the } \\
\text { achievement of goals by employees affect the effective use of financial resources by } \\
\text { employees in your organization? }\end{array}$ & 115 & 2.58 & .805 \\
\hline $\begin{array}{l}\text { To what extent does the action by your supervisor of rewarding employees on their } \\
\text { achievements affect the effective use of financial resources by employees in your } \\
\text { organization? }\end{array}$ & 115 & 2.51 & .718 \\
\hline
\end{tabular}




\begin{tabular}{|l|l|l|l|l|}
\hline Descriptive Statistics & & & \\
\hline $\begin{array}{l}|l| \\
\text { Achievement-Oriented Leadership Style }\end{array}$ & (M) & (SD) \\
\hline Effects of Achievement-Oriented Leadership Style on Product Quality & & & \\
\hline $\begin{array}{l}\text { To what extent has defining of clear goals by your supervisor affected the quality of } \\
\text { products produced by employees in your organization? }\end{array}$ & 111 & 4.07 & .374 \\
\hline $\begin{array}{l}\text { To what extent does the requirement of feedback by your supervisor on the achievement of } \\
\text { goals by employees affect the quality of products produced by employees in your } \\
\text { organization? }\end{array}$ & 111 & 3.26 & .643 \\
\hline $\begin{array}{l}\text { To what extent does your supervisor's behavior in rewarding employees on their } \\
\text { achievement of tasks affect the quality of products produced by employees in your } \\
\text { organization? }\end{array}$ & 111 & 3.34 & .610 \\
\hline Effects of Achievement-Oriented Leadership Style on Employee Satisfaction & & \\
\hline $\begin{array}{l}\text { Considering the clear defining of goals by your supervisor, how likely are you to refer } \\
\text { friends and family to work in your organization? }\end{array}$ & 110 & 4.14 & .438 \\
\hline $\begin{array}{l}\text { Considering your supervisors requirement of feedback on the achievement of goals by } \\
\text { employees, how likely are you to refer friends and family to work in your organization? }\end{array}$ & 110 & 4.15 & .485 \\
\hline $\begin{array}{l}\text { Considering the rewarding of employees on their achievement of goals by your supervisor, } \\
\text { how likely are you to refer friends and family to work in your organization? }\end{array}$ & 110 & 4.09 & .419 \\
\hline Effects of Achievement-Oriented Leadership Style on Innovation & & \multicolumn{3}{|l|}{} \\
\hline $\begin{array}{l}\text { To what extent does defining of goals by your supervisor affect the generation of new ideas } \\
\text { in your organization? }\end{array}$ & 110 & 4.77 & .569 \\
\hline $\begin{array}{l}\text { To what extent does the requirement of feedback on the achievement of goals by } \\
\text { employees affect the generation of new ideas by employees in your organization? }\end{array}$ & 109 & 4.69 & .676 \\
\hline $\begin{array}{l}\text { To what extent does your supervisor's role in rewarding employees on their achievement } \\
\text { affect the generation of new ideas by employees in your organization? }\end{array}$ & 110 & 3.35 & .806 \\
\hline
\end{tabular}

The results in Table 7 indicated that that respondents agreed that, on considering the behavior of supervisors in rewarding employees for achieving goals, they are very likely to refer friends and family to work in the organization $(M=4.09, S D=0.419)$ but were neutral on whether or not this behavior affects the generation of new ideas by employees $(M=3.35, S D=0.806)$.

\subsubsection{Correlation between Achievement-Oriented Leadership and Employee Performance}

Correlation analysis was conducted to examine the strength and direction of the relationship between achievement oriented leadership style and employee performance of senior managers of coffee trading companies in Kenya. Table 8 show the results of the correlations between the measures of achievement-oriented leadership style and employee performance. The Pearson's correlation coefficient reveals that there was a strong positive and significant correlation overall between achievement-oriented leadership and employee performance $r(117)=.911, p \leq .05$.

Table 8: Correlation between Achievement-Oriented Leadership style and Employee Performance

\begin{tabular}{|l|l|l|l|}
\hline \multirow{2}{*}{$\begin{array}{l}\text { Correlations } \\
\text { Achievement-Oriented }\end{array}$} & $\begin{array}{l}\text { Achievement-Oriented } \\
\text { Leadership Style }\end{array}$ & $\begin{array}{l}\text { Employee } \\
\text { Performance }\end{array}$ \\
\cline { 2 - 4 } & Peadership Style & 1 & $.911^{* *}$ \\
\cline { 2 - 4 } & Sig. (2-tailed) & & .000 \\
\cline { 2 - 4 } & $\mathrm{N}$ & 117 & 117 \\
\hline \multirow{3}{*}{ Employee Performance } & Pearson Correlation & $.911^{* *}$ & 1 \\
\cline { 2 - 4 } & Sig. (2-tailed) & .000 & 117 \\
\cline { 2 - 4 } & $\mathrm{N}$ & 117 & \\
\hline
\end{tabular}

**. Correlation is significant at the 0.05 level (2-tailed).

\subsubsection{Chi-Square Test for Achievement-Oriented Leadership}

The study sought to examine whether there was a statistically significant association between achievement oriented leadership style and employee performance. Table 9 shows the results of the chi-square test on achievement-oriented leadership style and employee performance.

Table 9: Chi-Square Test on Achievement Oriented Leadership Style

\begin{tabular}{|l|l|}
\hline & Achievement-Oriented Leadership style \\
\hline Pearson Chi-Square & $263.021^{\mathrm{a}}$ \\
\hline Df & 28 \\
\hline Asymp. Sig. (2-sided) & .000 \\
\hline$* *$ Correlation is significant at the 0.05 level (2-tailed). \\
\hline
\end{tabular}


The results in Table 9 indicated there was sufficient evidence to conclude that there is a statistical significant association between achievement-oriented leadership style and employee performance $\chi^{2}(28, N=117)$ $=263.021, p \leq .05$

\subsubsection{Regression analysis and Hypothesis Testing}

The study tested the hypothesis:

$\mathbf{H}_{\mathbf{0} 2}$ : Achievement-oriented leadership style does not have a significant influence on employee performance of coffee trading companies in Kenya.

\subsubsection{Regression Model Summary}

Table 10: Regression Model Summary for Achievement-Oriented Leadership Style Model Summary

\begin{tabular}{|l|l|l|l|l|}
\hline Model & R & R Square & Adjusted R Square & Std. Error of the Estimate \\
\hline 1 & $.401^{\mathrm{a}}$ & .161 & .153 & .404 \\
\hline
\end{tabular}

The study findings in Table 10 indicate that achievement-oriented leadership style explained $16.1 \%$ variation in employee performance among the senior managers of coffee trading companies, $R^{2}=.161 \mathrm{implying}$ that $16.1 \%$ of the changes in employee performance of senior managers could be explained by the achievementoriented leadership style.

\subsubsection{Regression ANOVA}

Table 11 presents the results of the regression ANOVA for achievement-oriented leadership style and employee performance and these findings indicate that the model was statistically significant in linking achievementoriented leadership style and employee performance among senior managers of coffee trading companies in Kenya, $F(1,108)=20.686, p<.05$. The study findings reveal achievement-oriented leadership style positively and significantly influences employee performance.

Table 11: Regression ANOVA for Achievement-Oriented Leadership Style

\begin{tabular}{|c|c|c|c|c|c|c|}
\hline \multicolumn{7}{|c|}{ ANOVA $^{\mathbf{a}}$} \\
\hline \multicolumn{2}{|c|}{ Model } & Sum of Squares & $\mathrm{df}$ & Mean Square & $\mathrm{F}$ & Sig. \\
\hline \multirow[t]{3}{*}{1} & Regression & 3.368 & 1 & 3.368 & 20.686 & $.000^{\mathrm{b}}$ \\
\hline & Residual & 17.586 & 108 & .163 & & \\
\hline & Total & 20.955 & 109 & & & \\
\hline
\end{tabular}

**Correlation is significant at the 0.05 level (2 tailed).

\subsubsection{Regression Coefficients}

Multiple linear regression analysis was conducted with the purpose of determining the magnitude and direction of the relationship between achievement-oriented leadership style and employee performance among senior managers of coffee trading companies in Kenya.

Table 12: Regression Coefficients for Achievement-Oriented Leadership Style

\section{Coefficients $^{\mathrm{a}}$}

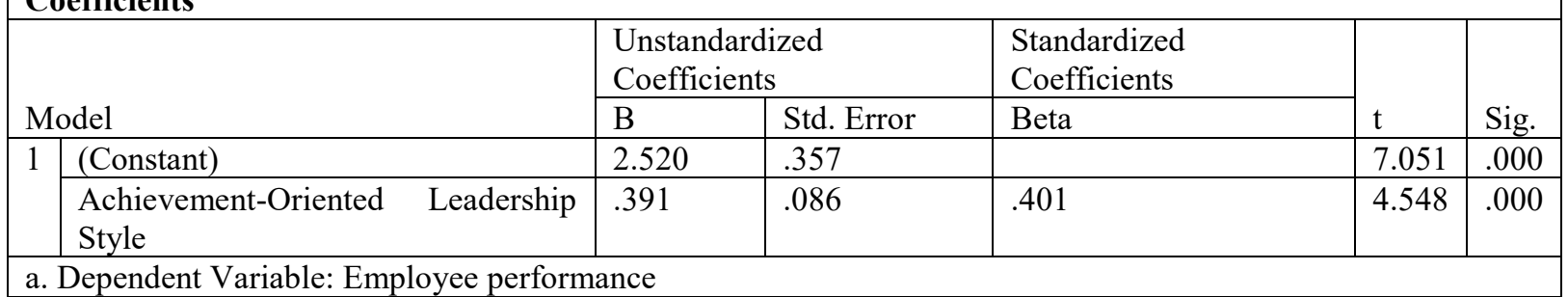

The study findings in Table 12 shows that achievement-oriented leadership style positively and significantly predicted employee performance, $\beta=0.391, t(116)=4.548, p \leq .05$. This implied that a unit increase in achievement-oriented leadership style would lead to a significant increase in employee performance among the senior managers of coffee trading companies in Kenya by 0.391 units. The study hence concluded that achievement-oriented leadership style positively and significantly predicted employee performance of senior managers of coffee trading companies in Kenya.

\subsection{DISCUSSIONS, CONCLUSION S AND RECOMMENDATIONS \\ 5.1 Discussion of the Findings \\ 5.1.1 Directive leadership Style}

The first objective of this study was to examine the extent to which directive leadership style affected employee performance of coffee trading companies in Kenya. The results from the correlational analysis revealed that directive leadership style had a negative and significant correlation with employee performance, $r(116)=-.187$, $\mathrm{p} \leq .05$. These findings concur with those of Mendez et al. (2013), whose study of employees in construction 
companies exposed a negative and significant relationship between directive leadership style and the utilization of financial resources by employees $(\mathrm{r}=$ of $-0.145, \mathrm{P} \leq .05)$. The study results also agree with the findings of the study by Euwema et al. (2014) which found that leaders who pushed for adoption of rules, procedures, and routine practices compromised follower trust and these behaviors negatively affected the quality of production ( $\mathrm{r}$ $=-.15, p \leq .05$ ).

The findings of this study, however, disagree with the findings of two studies of head teachers and staff of schools. For instance, a study by Ijah (2012) of staff of secondary schools in Nigeria where $70 \%$ of the principals applied a directive leadership style found that the use of directive leadership style had a positive and significant relationship with the job performance of the teaching staff $(\mathrm{r}=0.5007, p \leq .05)$. Another study by Wachira et al. (2013) of staff in public primary schools in Nakuru county in Kenya found a positive and significant relationship existed between the directive leadership style of principals and teaching staff (rho $(305)=0.592, p \leq .05)$.

\subsubsection{Achievement-Oriented Leadership Style}

The second objective of this study was to examine the extent to which achievement-oriented leadership style affected employee performance. The results of the correlation analysis indicated that achievement-oriented leadership style was significantly related to employee performance, $\mathrm{r}(117)=0.911, p \leq .05$. The findings of this study agree with those of Spreier et al. (2016) who found that the desire to achieve is a major source of strength for organizations in sustaining performance for the long term as the behavior of setting goals fuels growth and generates passion and energy in employees to succeed. The findings of the study also resonate with those of Khuong and Hoang (2015) who found that setting benchmarks for achievement and recognition of performers was critical for the success of an organization. Where employees believed that there would be no difference between the treatment of high performers and poor performers, they stopped placing any extra effort in their work and were not motivated to aim for higher quality productivity so did not perform to optimal levels.

On the other hand, findings of this study disagreed with those of a study by Sagnak (2016) who found a negative relationship between achievement oriented leadership style and performance of employees who were low in conscientiousness and emotional stability. Goal-focused leadership was found to lead to burn out and high levels of emotional exhaustion.

\subsection{Conclusion}

\subsubsection{Directive Leadership and Employee Performance}

The multiple linear regression results indicated that directive leadership style negatively and significantly predicted employee performance $\mathrm{R} 2=.035, \mathrm{~F}(1,114)=4.141, \mathrm{p} \leq .05 ; \beta=-.153, \mathrm{p} \leq .05$. The study results led to rejecting the null hypothesis that directive leadership style had no significant influence on employee performance. From the findings of this study, it was concluded that leaders in the coffee industry who use directive leadership style with their employees do not realize effective utilization of financial resources nor can they achieve product quality enhancements, employee satisfaction or innovation and that leaders using directive leadership style would result in degrading employee performance.

\subsubsection{Achievement-Oriented Leadership and Employee Performance}

The multiple linear regression results of the study established that achievement-oriented leadership style significantly predicted the employee performance, $\mathrm{R} 2=.161, \mathrm{~F}(1,116)=20.686, \mathrm{p} \leq .05 ; \beta=0.391, \mathrm{p} \leq .05$. The results of this study led to rejecting the null hypothesis that achievement-oriented leadership style had no significant influence on employee performance. The study concluded that when leaders of coffee companies set goals for employees and expect high standards of them, employee performance is enhanced.

\subsection{Recommendations}

\subsubsection{Recommendations for improvement}

\subsubsection{Directive Leadership and Employee Performance}

The study established a negative and significant relationship between directive leadership style and employee performance within senior managers working for coffee trading companies in Kenya. The senior managers of coffee trading companies should exercise caution on the use of directive leadership style and avoid this style unless it is absolutely essential to do so based on the task at hand or other organizational factors. For instance, directive leadership style may be necessary to push through an agenda that is beneficial to the organization or for unpopular decisions which do not serve every employee's self-interest but which are needed to improve productivity and keep the organization moving in the right direction. It is also recommended that where there is need to use a directive leadership style, leaders should exercise caution and use it sparingly and where it is possible, leaders should avoid its use or combine its use with other more effective leadership styles.

\subsubsection{Achievement-Oriented Leadership and Employee Performance}

The study found that achievement-oriented leadership style positively and significantly influenced financial resources, product quality, employee satisfaction and innovation. The study found that achievement-oriented leadership style positively and significantly predicted employee performance. Kenyan coffee trading companies 
should adopt the use of achievement-oriented leadership style as a system of leadership and, leaders in coffee trading companies should define goals, give consistent feedback on the achievement of the goals and reward performing employees. This will enhance employee performance which will have the influence of improved performance of the organization as a whole.

\subsubsection{Recommendation for Further Research}

The study recommends that a similar study should be carried out to assess the influence of path-goal leadership style on supervisory level managers of coffee trading organizations.

\section{REFERENCES}

Abbah, T. M. (2014). Employee Motivation: The Key to Effective Organizational Management in Nigeria. IOSR Journal of Business and Management (IOSR-JBM) e-ISSN: 2278-487X, p-ISSN: 2319-7668, Vol 16, Issue 4. Version I, pp 01-08.

Baregheh, A., Rowley, J., \& Sambrook, S. (2015). Towards a multidisciplinary definition of innovation. Management Decision , 47, 1323-1339.

Basit, A., Sebastian, V., \& Hassan, Z. (2017). Impact of leadership style on employee performance (A Case study on a private organization in Malaysia). International Journal of Accounting \& Business Management www.ftms.edu.my/journals/index.php/journals/ijabm Vol. 5 (No.2), November, 2017 ISSN: 2289-4519 DOI: $24924 / \mathrm{ijabm} / 2017.11 / \mathrm{v} 5$. iss2/112.130

Casson, R. J., Franzco, \& Farmer, L. D. M. (2014). Understanding and checking the assumptions of linear regression: a primer for medical researchers. Clinical and Experimental Ophthalmology 2014; 42: 590-596 doi: $10.1111 /$ ceo. 12358

Flamholtz, E. G., \& Randell, Y (2016). Growing Pains: Building Sustainably Successful Organizations. John Wiley \& Sons, Inc., New Jersey 244-320

Henseler, J., Ringle, C. M., \& Sinkovics, R. R. (2015). "The use of partial least squares path modeling in international marketing". Advances in International Marketing. vol.20, 277-319.

Hui, K. L., Xin, L. J., Di, L. S., Yung, N. K., \& Ying, S. K. (2014). Working Performance in Financial Sector, (August)

Ijah, A. (2012). Leadership styles of principals and job performance of staff in secondary schools in Delta state of Nigeria. An international journal of arts and humanities, Vol 2, 224-245. ISSN 2225-8590.

International Coffee Organization (ICO) (2015). Sustainability of the Coffee Sector in Africa. International Coffee Council, 114 (5) Rev.1

Iqbal, N., Anwar, S., \& Haider, N. (2015). Effects of leadership style on employee performance. Arabian journal of business management review, 5(146).

Javaid, M. F. (2012). Leadership Style enhances the employee Organizational Commitment: A case study of educational institutions in Lahore. Journal of management, statistics and social sciences, 1(1), 64-77.

Khalid, S., \& Irshad, M. Z. (2015). Job Satisfaction among Bank Employees in Punjab, Pakistan: A Comparative Study. European journals of social sciences , 17 (4), 570-577.

Khuong, M. N., \& Hoang, M. D. (2015). The effects of leadership styles on employee motivation in auditing companies in Ho Chi Minh City, Vietnam. International Journal of trade, economics and finance, 6( 4), 210-217.

Kiboss, J. K., \& Jemiryott, H. K. (2014). Principals' Leadership Styles and Secondary School Teachers' Job Satisfaction in Nandi South District, Kenya. Journal of Education and Human Development , 3( 2), 493-509 ISSN: 2334-296X (Print), 2334-2978.

Kieyah, J., \& Lesiyampe, L. (2016). Report of the National Task Force on Coffee Sub-Sector Reforms

Lumbasi, G., K'Aol, G., \& Ouma, C. (2016). The Effect of Achievement Oriented Leadership Style on the Performance of COYA Senior Managers in Kenya. International Journal of Novel Research in Marketing Management and Economics, , 3(2), 118-125, ISSN 2394-7322.

Lussier, R. N., \& Achua, C. F. (2013). Leadership: Theory, Application and Skill Development, pp. 161-170.

Mahdi, O. R., Mohd, E. S., \& Almsafir, M. K. (2014). Empirical Study on the Impact of Leadership On Organizational Commitment in Plantation Companies in Malaysia, Elsevier Ltd. Procedia - Social and Behavioral Sciences , 109, 1076-1087.

Marshall, V. \& Rossman, S. A. (2016). The Oxford Handbook of Participation in Organizations. Oxford University Press.

Mbithi, D. (2018). Nairobi Coffee Exchange. Retrieved from http://nairobicoffeeexchange.co.ke/

Mcshane, S. L., \& Von Glinow, M. A. (2012). Organizational Behavior: The power of People and Leadership in What the Best MBAs Know,. New York: McGraw-Hill, 187-203.

Mohammed, U., Yusuf, M., Sanni, M. I., Ifeyinwa, N. T., Bature, U. N., \& Kazeem, O. A. (2014). The Relationship between Leadership Styles and Employees' Performance in Organizations (A Study of Selected Business Organizations in Federal Capital Territory, European Journal of Business and 
Management Online, 6(22)2222-2839.

Monroy L., Mulinge W., Witwer M. (2013), Analysis of incentives and disincentives for coffee in Kenya. Technical notes series, MAFAP, FAO, Rome.

Nikoloski, K. (2015). Leadership and Management: Practice of the Art of Influence. Annals of the „Constantin Brâncuşi” "University of Târgu Jiu, , Economy Series, Issue 1, volume II/2015.

Northouse, P. G. (2016). Leadership: Theory and practice (7th edition). Thousand Oaks, California, USA, Sage Publications.

Ojokuku, R. M., Odetayo, T. A., \& Sajuyigbe, A. S. (2014). Impact of leadership style on organizational performance : A case study of Nigerian Banks. American Journal of Business and Management , 1(4), 202207.

Reio, T. G., \& Shuck, B. (2015). Exploratory Factor Analysis: Implications for Theory, Research, and Practice. Advances in Developing Human Resources, 17(1), 1225. https://doi.org/10.1177/1523422314559804

Rennie, M., Meaney, M., Hazlewood, J., Kumra, G., \& Dias, A. K. (2015). McKinsey on Organization Agility and Organization Design, pp 6-28

Sougui, A. O., Bon, A. T., \& Hassan, H. M. (2015). The Impact of Leadership Styles on Employees' performance in Telecom Engineering companies,. Australian Journal of Basic and Applied Sciences , 8(4).

Stoker, J. I. (2014). Effects of team tenure and leadership in self-managing teams. Personnel Review , 37(5), 564-582.

Wakabi, B. M. (2016). Leadership style and staff retention in organizations. International Journal of Science and Research, 5(1), pp. 412-416.

Wanjala, M. N. (2014). The influence of leadership style on employees' job performance in the hospitality industry: case study of safari park hotel. Unpublished manuscript, United States Inernational University, Nairobi, Kenya.

Wart, M. V. (2015). Dynamics of Leadership in Public Service,. Armonk, NY, London, England,: M. E. Sharpe.

Wendt, H., Euwema, M.C., \& Emmerik, H. (2009). Leadership and team cohesiveness across cultures, Leadership Quarterly, Vol 20, 358-370. https://doi.org/10.1016/j.leaqua.2009.03.005.

Yukl, G. (2015). Leadership in organizations (7th ed.). Upper Saddle Rive, NJ: Prentice-Hall. 